\title{
Effect of long-term vineyard monoculture on rhizosphere populations of pseudomonads carrying the antimicrobial biosynthetic genes phID and/or hcnAB
}

\author{
Miroslav Svercel ${ }^{1}$, Danilo Christen ${ }^{1}$, Yvan Moënne-Loccoz ${ }^{2,3,4}$, Brion Duffy ${ }^{5}$ \& Geneviève Défago ${ }^{1}$ \\ ${ }^{1}$ Plant Pathology, Institute of Integrative Biology, Zürich, Switzerland; ${ }^{2}$ Université de Lyon, Lyon, France; ${ }^{3}$ Université Lyon 1, Villeurbanne, France; ${ }^{4} \mathrm{CNRS}$ \\ UMR5557, Ecologie Microbienne, Villeurbanne, France; and ${ }^{5}$ Agroscope Changins-Wädenswil, Swiss Federal Research Station for Horticulture, Plant \\ Protection Division, Wädenswil, Switzerland
}

\begin{abstract}
Correspondence: Geneviève Défago, Plant Pathology, Institute of Integrative Biology, ETH-Zürich, 8092 Zürich, Switzerland. Tel.: +4144632 3869; fax: +4144632 1572; e-mail: genevieve.defago@agrl.ethz.ch
\end{abstract}

Present address: Danilo Christen, Agroscope Changins-Wädenswil Research Station ACW, Centre des Fougères, CH-1964 Conthey, Switzerland.

Received 27 August 2008; revised 18 November 2008; accepted 9 December 2008.

First published online 6 February 2009.

DOI:10.1111/j.1574-6941.2009.00649.x

Editor: Kornelia Smalla

Keywords

biological control; monoculture; Vitis; Pseudomonas; hydrogen cyanide; 2,4diacetylphloroglucinol.

\begin{abstract}
The impact of repeated culture of perennial plants (i.e. in long-term monoculture) on the ecology of plant-beneficial bacteria is unknown. Here, the influence of extremely long-term monocultures of grapevine (up to 1603 years) on rhizosphere populations of fluorescent pseudomonads carrying the biosynthetic genes phlD for 2,4-diacetylphloroglucinol and/or $h c n A B$ for hydrogen cyanide was determined. Soils from long-term and adjacent short-term monoculture vineyards (or brushland) in four regions of Switzerland were baited with grapevine or tobacco plantlets, and rhizosphere pseudomonads were studied by most probable number (MPN)-PCR. Higher numbers and percentages of phlD ${ }^{+}$and of $h c n A B^{+}$rhizosphere pseudomonads were detected on using soil from long-term vineyards. On focusing on $p h l D$, restriction fragment length polymorphism profiling of the last phlD-positive MPN wells revealed seven phlD alleles (three exclusively on tobacco, thereof two new ones). Higher numbers of phlD alleles coincided with a lower prevalence of the allele displayed by the well-studied biocontrol strain Pseudomonas fluorescens F113. The prevalence of this allele was $35 \%$ for tobacco in long-term monoculture soils vs. $>60 \%$ in the other three cases. We conclude that soils from long-term grapevine monocultures represent an untapped resource for isolating novel biocontrol Pseudomonas strains when tobacco is used as bait.
\end{abstract}

\section{Introduction}

An important beneficial feature of certain long-term crop monocultures is their role in the suppression of soil-borne plant pathogens that cause root rot, crown rot, vascular wilt and damping-off diseases of many plant species (Weller et al., 2002; Moënne-Loccoz \& Défago, 2004; Haas \& Défago, 2005; Gardener, 2007). In the case of grapevine, for instance, roots are attacked by parasitic nematodes, fungi for example Armillaria mellea, Phymatotrichum omnivorum or Rosellinia necatrix (Winkler, 1962), and bacteria for example Agrobacterium tumefaciens or Agrobacterium vitis (Burr et al., 1998), which contribute to replant disease and therefore render replanting of grapevine in a vineyard difficult or even impossible. The facts that (1) certain sites can be replanted repeatedly and (2) old grapevines still have healthy roots suggest that the soil of these vineyards is suppressive to soilborne diseases.

Studies of disease-suppressive soils have been limited to monocultures of several years to a few decades for obvious practical reasons, and the impact of extremely long-term monocultures (i.e. beyond many decades) on populations of key bacterial antagonists has seldom been examined, especially in the case of perennial species (Landa et al., 2006). Grapevine offers a unique opportunity to study extremely long-term monocultures since vineyards dating back to preRoman times exist in Switzerland (Schlegel, 1973) and elsewhere in Europe. Additionally, for over a century, grapevine production has involved only a very few insect-resistant rootstock lines, on which a rich diversity of cultivars were grafted (Granett et al., 2001). The fact that these extremely long-term and little diverse monocultures continue to sustain 
healthy plants and expected yield points to the likely selection of a beneficial contingent of rhizosphere microorganisms.

Studies on the establishment and dynamics of soil suppressiveness to particular diseases indicate that the main factor involved is a shift in specific groups or subgroups of plant-beneficial microorganisms, rather than a change in the size or the activity of the whole microbial community (Mazzola, 2004). This selection process takes place at the plant species or even at the cultivar level (Garbeva et al., 2004; Mazzola et al., 2004; Okubara et al., 2004; Picard et al., 2004; Rotenberg et al., 2007). Root-colonizing fluorescent pseudomonads that are antagonistic towards phytopathogens, and more specifically Pseudomonas genotypes that produce the biocontrol compounds hydrogen cyanide (HCN) and 2,4-diacetylphloroglucinol (Phl), have been repeatedly associated with disease suppressiveness of soils (Haas \& Défago, 2005; Weller et al., 2007).

$\mathrm{Phl}$ is a natural antimicrobial polyketide that is critical for the efficacy of many inoculated Pseudomonas biocontrol agents (Keel et al., 1992; Weller et al., 2002). The phl biosynthetic locus includes the structural gene phlD (Bangera \& Thomashow, 1999; Paulsen et al., 2005), which has been used widely as a genetic marker in population studies (McSpadden Gardener \& Weller, 2001; McSpadden Gardener et al., 2001; Ramette et al., 2001, 2003b, 2006; Landa et al., 2002a, b, 2006; Weller et al., 2007). The assessment of the genotypic diversity of $p h l D^{+}$Pseudomonas spp. has shown a strong, although not absolute, correlation between restriction fragment length polymorphism (RFLP) of the phlD gene and genomic properties assayed using various PCR techniques (Mavrodi et al., 2001; Ramette et al., 2001).

$\mathrm{HCN}$ is also a biocontrol determinant in fluorescent pseudomonads (Haas \& Keel, 2003; Moënne-Loccoz \& Défago, 2004). It is produced by almost all $\mathrm{Phl}^{+}$strains, as well as a range of $\mathrm{Phl}^{-}$pseudomonads (Ramette et al., 2003a), including biocontrol strains (Rezzonico et al., 2007).

The general objective of this study was to evaluate the abundance and diversity of $p h l D^{+}$and $h c n A B^{+}$rhizosphere pseudomonads in vineyards under long-term monoculture or in short-term counterparts, based on the hypothesis that sustainable long-term grapevine monoculture should enrich in antagonistic pseudomonads. To provide comparable rhizosphere conditions, soils from different field conditions were sampled and grown with grapevine or tobacco, a reference bait plant known to favour rhizosphere colonization by $\mathrm{HCN}^{+} \mathrm{Phl}^{+}$pseudomonads (Ramette et al., 2003b).

\section{Materials and methods}

\section{Survey of long-term vineyards in Switzerland}

Several sites with extremely long-term monoculture vineyards (e.g. planted since the first millennium without interruption) can be found in Switzerland in official documents of the political communities or monasteries. They are located in hilly regions, and such long-standing monocultures indicate that the areas are suitable for sustainable wine production. Therefore, the whole hill is usually planted with grapevine, which renders the identification of comparable, nearby sites without a history of long-term grapevine monoculture (i.e. sites with short-term monoculture vineyards or a different land usage) very difficult. Our survey led to the identification of four such situations in different geographic regions of Switzerland. In two regions, we found (Basel and Neuchâtel) an old vineyard adjacent to a recent one (i.e. planted with grapevine since $<60$ years). In another region (Valais), we found one old vineyard adjacent to a brushland, and in a fourth region (Zürich) a young vineyard was about $500 \mathrm{~m}$ from the old one, but both were on the same morainic layer. Because grapevine is replanted approximately every 20-25 years, it means that the old vineyards were planted 40-60 times with grapevine and the young ones one to three times. The soil parameters were similar between both sites within the same location, but differed substantially between the locations (e.g. clay content, Table 1).

\section{Soil sampling and baiting plants}

Soils were collected in November 2002 from vineyards in the four Swiss regions surveyed, i.e. Basel, Neuchâtel, Valais, Zürich and from a tobacco black root rot-suppressive soil located in Morens [soil MS8; Stutz et al. (1986)] (Table 1). Soil was taken at $10-30 \mathrm{~cm}$ depth using sterilized shovels, at each of five locations in the centre of each plot (in different rows between stocks in the vineyards). Root residues and stones were removed and soil samples from the same site were pooled. At each site, the same sampling procedure was applied on the same day to collect two composite samples (A and B). Each soil was kept at $15^{\circ} \mathrm{C}$ before use. Samples A were used within 4 days after sampling (batch A) and samples B within 14 days after sampling (batch B).

Grapevine baiting plants (Vitis riparia $\times$ Vitis rupestris 3309 accession RAC 1.1) corresponding to a commonly used rootstock in Switzerland were propagated in vitro on ENTAV medium (Galzy, 1990). Grapevine plants were allowed an adaptation period of 12 days to build the cuticle ( 6 days in a covered tube, followed by 6 days in an uncovered tube) before planting in soils. Tobacco seedlings (Nicotiana glutinosa L.) were grown for 5 weeks in sand and fertilized with Knop's nutrient solution (Ziegler, 1983) before transplanting into soil, as described by Stutz et al. (1986). Grapevine or tobacco seedlings were transferred to soil-filled $300 \mathrm{~cm}^{3}$ plastic pots with drainage holes at the bottom (one plant per pot, eight pots per batch for each soil and for each plant species). Plants were grown for a further 3 weeks and were watered as needed with distilled water to maintain the soil water 
Table 1. Characteristics* of soils

\begin{tabular}{|c|c|c|c|c|c|c|c|c|c|}
\hline \multirow{2}{*}{$\frac{\text { Soils }^{\dagger, \ddagger}}{\text { Coordinates }^{\S}}$} & \multicolumn{2}{|l|}{ Basel } & \multicolumn{2}{|c|}{ Neuchâtel } & \multicolumn{2}{|l|}{ Valais } & \multicolumn{2}{|l|}{ Zürich } & \multirow[t]{2}{*}{ MS8 Morens } \\
\hline & & & & & & & & & \\
\hline EW & 610050 & 610045 & 553175 & 553200 & 580145 & 580150 & 703125 & 702150 & 559300 \\
\hline SN & 257100 & 257170 & 197265 & 197260 & 113135 & 113135 & 276120 & 276315 & 190850 \\
\hline Grapevine monoculture in years" & 32 & 1603 & 53 & 1005 & 0 & 952 & 8 & 1169 & 0 \\
\hline \multicolumn{10}{|l|}{ Particle size distribution $\|$} \\
\hline Clay (\%) & 41.7 & 36.5 & 24.2 & 26.7 & 13.2 & 13.2 & 24.8 & 20.5 & 14.0 \\
\hline Silt (\%) & 41.5 & 44.8 & 48.9 & 51.2 & 26.7 & 30.0 & 28.6 & 24.4 & 32.4 \\
\hline Sand (\%) & 16.8 & 18.7 & 26.9 & 22.1 & 60.1 & 56.8 & 46.6 & 55.1 & 53.6 \\
\hline \multicolumn{10}{|l|}{ Exchange capacity ( $\mathrm{BaCl}_{2}$ triethanolamine) } \\
\hline Cation exchange capacity (CEC) $\left(\mathrm{cmol} \mathrm{kg}^{-1}\right)$ & 26.4 & 21.5 & 12.5 & 14.4 & 11.5 & 10.6 & 14.4 & 11.9 & 7.1 \\
\hline Saturation CEC (\%) & 88.7 & 87.6 & 100 & 92.9 & 100 & 100 & 87.9 & 91.5 & 100 \\
\hline$K(\%)$ & 3.4 & 4.1 & 4.3 & 3.1 & 1.2 & 2.6 & 2.9 & 4.0 & 3.0 \\
\hline $\mathrm{Ca}(\%)$ & 79.0 & 74.3 & 83.0 & 79.1 & 91.8 & 85.5 & 72.7 & 72.8 & 92.5 \\
\hline $\mathrm{Mg}(\%)$ & 5.9 & 8.8 & 12.1 & 9.5 & 6.3 & 11.1 & 11.9 & 14.1 & 3.5 \\
\hline $\mathrm{Na}(\%)$ & 0.4 & 0.4 & 0.6 & 1.2 & 0.7 & 0.7 & 0.5 & 0.6 & 1.0 \\
\hline $\mathrm{H}(\%)$ & 11.3 & 12.4 & 0 & 7.1 & 0 & 0 & 12.1 & 8.5 & 0 \\
\hline \multicolumn{10}{|l|}{ Soluble element } \\
\hline $\mathrm{B}$ (hot water) $\left(\mathrm{mg} \mathrm{kg}^{-1}\right)$ & 1.59 & 2.15 & 0.92 & 0.90 & 0.86 & 1.46 & 1.18 & 1.14 & 0.69 \\
\hline \multicolumn{10}{|l|}{ Reserve elements $\left(\mathrm{NH}_{4}\right.$-Ac. +EDTA $\left.1: 10\right)$} \\
\hline $\mathrm{P}\left(\mathrm{mg} \mathrm{kg}^{-1}\right)$ & 141 & 143 & 122 & 82 & 100 & 516 & 194 & 322 & 136 \\
\hline $\mathrm{K}\left(\mathrm{mg} \mathrm{kg}^{-1}\right)$ & 844 & 870 & 317 & 314 & 110 & 246 & 294 & 321 & 126 \\
\hline $\mathrm{Ca}\left(\mathrm{g} \mathrm{kg}^{-1}\right)$ & 55.1 & 86.5 & 77.3 & 69.3 & 49.8 & 54.0 & 13.6 & 33.5 & 28.9 \\
\hline $\operatorname{Mg}\left(\mathrm{mg} \mathrm{kg}^{-1}\right)$ & 540 & 830 & 710 & 658 & 486 & 664 & 432 & 440 & 230 \\
\hline \multicolumn{10}{|l|}{ Oligo elements $\left(\mathrm{NH}_{4}\right.$-Ac. +EDTA $\left.1: 10\right)\left(\mathrm{mg} \mathrm{kg}^{-1}\right)$} \\
\hline $\mathrm{Cu}$ & 196 & 290 & 171 & 156 & 7.9 & 139 & 149 & 183 & 4.5 \\
\hline $\mathrm{Fe}$ & 518 & 637 & 443 & 406 & 508 & 515 & 606 & 679 & 367 \\
\hline $\mathrm{Zn}$ & 44.5 & 147.4 & 15.4 & 13.2 & 9.9 & 32.1 & 20.1 & 11.5 & 3.9 \\
\hline $\mathrm{Mn}$ & 252 & 143 & 329 & 325 & 81 & 102 & 450 & 372 & 362 \\
\hline \multicolumn{10}{|l|}{ Other criteria } \\
\hline Organic matter (titration) (\%) & 1.6 & 4.4 & 1.8 & 1.6 & 3.8 & 2.3 & 2.9 & 1.9 & 4.4 \\
\hline $\mathrm{pH}$ (water) & 7.9 & 7.5 & 8.0 & 8.0 & 7.8 & 8.0 & 7.4 & 7.7 & 7.6 \\
\hline $\mathrm{CaCO}_{3}$ (total) $(\%)$ & 7 & 29 & 23 & 19 & 15 & 18 & 2 & 8 & 14 \\
\hline $\mathrm{N}$ total (Kjeldahl) (\%) & 0.25 & 0.27 & 0.11 & 0.11 & 0.22 & 0.16 & 0.18 & 0.12 & 0.12 \\
\hline
\end{tabular}

*Soils were analyzed by the Swiss soil testing service, Nyon (Switzerland).

†Vineyards were preselected by D. Christen (ETHZ diploma thesis 2001).

¥The crop planted before the short-term vineyards: Zürich, intensive annual cropping system; Neuchâtel, meadow; Basel, orchard. The brushland in Valais is dominated by Prunus spinosa with a few bushes of Prunus triloba.

${ }^{\S}$ The National Map of Switzerland $(1: 25.000)$ was used for precise geographic coordinates of the plots. Two 6 -number codes were used for each plot. The first code was for the east-west orientation (EW) and the second code for the south-north orientation (SN). The three first numbers of the codes correspond to the kilometers indicated in the map (every $4 \mathrm{~cm}$ line $=1 \mathrm{~km}$ ). Each kilometer on the map was divided into 40 parts corresponding to the fourth and the fifth numbers of the code (every millimeter from 01 to 40). The last number of the code corresponds to a further division of the 40 parts and represents every half-millimeter $(0=$ full millimeter or $5=$ half-millimeter).

The years of grapevine monoculture were identified from the following sources: Basel short (ancient photo documentation and dated plantation); Basel long $\left({ }^{14} \mathrm{C}\right.$ dating - Ancient 'Centre de Recherches de Sandoz'); Neuchâtel short (document of founding of the vineyard); Neuchâtel long (documented in the 'Musée d'Art et d'Histoire' in Neuchâtel); Valais long (documented in cantonal archives in Sion), Zürich short (document of founding of the vineyard) and Zürich long (documented in archives of St Gallen).

"Soil texture was silt loam (Basel, Neuchâtel and Zürich) or sandy loam (Valais and Morens).

content at $20 \% \mathrm{w} / \mathrm{w}$. The growth chamber was set up at $22^{\circ} \mathrm{C}$, $70 \%$ relative humidity and $16 \mathrm{~h}$ of light $\left(80 \mathrm{mE} \mathrm{m}^{-2} \mathrm{~s}^{-1}\right)$.

\section{Quantification of rhizosphere pseudomonads}

Rhizospheric pseudomonads were studied, at 3 weeks, as described by Ramette et al. (2003b). Briefly, the plants were removed from the pots and the root systems were shaken free of loosely adhering soil. Each root system (with closely adhering soil) was cut, weighted and transferred into a 15$\mathrm{mL}$ tube containing $9.5 \mathrm{~mL}$ of $0.9 \% \mathrm{NaCl}$ solution. Each tube was shaken for $40 \mathrm{~min}$ at 250 r.p.m., vortexed for $10 \mathrm{~s}$ and the sample suspension was used to inoculate $(15 \mu \mathrm{L}$ added per well) four wells of a 96-well microtitration plate 
containing $135 \mu \mathrm{L}$ of $\mathrm{KB}^{+++}$medium, i.e. King's B medium (King et al., 1954) supplemented with actidione $\left(100 \mu \mathrm{g} \mathrm{mL}^{-1}\right)$, chloramphenicol $\left(13 \mu \mathrm{g} \mathrm{mL}^{-1}\right)$ and ampicillin $\left(40 \mu \mathrm{g} \mathrm{mL}^{-1}\right)$, for selection of fluorescent pseudomonads (Raaijmakers et al., 1997). Serial 10-fold dilutions of each inoculated well were prepared in the microtitration plates, which were incubated for 3 days at $27^{\circ} \mathrm{C}$ with shaking (150 r.p.m.). Bacterial growth was assessed visually and the number of pseudomonads was determined using the most probable number (MPN) technique (Alexander, 1982; Garthright \& Blodgett, 2003) (see Supporting Information, Fig. S1). For storage at $-80{ }^{\circ} \mathrm{C}$, glycerol was added to all wells to achieve a final concentration of $40 \%$ and microtitration plates were sealed.

\section{Quantification of $p h I D$ and $h c n A B$ rhizosphere pseudomonads}

The numbers of $p h l D^{+}$and $h c n A B^{+}$pseudomonads in the rhizosphere were determined using an MPN-PCR approach (Ramette et al., 2005). Briefly, $20 \mu \mathrm{L}$ from each microtitration plate well showing bacterial growth was transferred into $150 \mu \mathrm{L}$ of lysis solution $(50 \mathrm{mM} \mathrm{KCl} ; 0.1 \%$ Tween 20 ; and $10 \mathrm{mM}$ Tris-HCl, $\mathrm{pH}$ 8.3) (Keel et al., 1996) in a PCR microtitration plate (Simport Plastics, Beloeil, Canada). The suspension was centrifuged at $4025 \mathrm{~g}$ for $2 \mathrm{~min}$ and incubated for $10 \mathrm{~min}$ at $99^{\circ} \mathrm{C}$. The heat-lysed suspension was frozen at $-20^{\circ} \mathrm{C}$ for $30 \mathrm{~min}$. After thawing, $4 \mu \mathrm{L}$ of the supernatant was taken for PCR.

Amplification of phlD was performed using the forward primer B2BF (25-mer 5'-ACCCACCGCAGCATCGTTTATGAGC-3') and the reverse primer BPR4 (26-mer 5'CCGCCGGTATGGAAGATGAAAAAGTC-3') (McSpadden Gardener et al., 2001). Amplifications were carried out in $12-\mu \mathrm{L}$ reaction mixtures containing $4 \mu \mathrm{L}$ of lysed bacterial suspension, $1 \times$ PCR buffer (Amersham Pharmacia, Uppsala, Sweden), bovine serum albumin $\left(0.5 \mathrm{~g} \mathrm{~L}^{-1}\right.$; Fluka, Buchs, Switzerland), 5\% dimethyl sulphoxide (Fluka), $100 \mu \mathrm{M}$ each of dATP, dCTP, dGTP and dTTP (Amersham Pharmacia), $0.40 \mu \mathrm{M}$ of each primer and $1.4 \mathrm{U}$ of Taq DNA polymerase (Amersham Pharmacia). The initial denaturation ( $2 \mathrm{~min}$ at $94{ }^{\circ} \mathrm{C}$ ) was followed by 35 cycles of $94^{\circ} \mathrm{C}$ for $30 \mathrm{~s}, 60^{\circ} \mathrm{C}$ for $30 \mathrm{~s}$ and $72^{\circ} \mathrm{C}$ for $60 \mathrm{~s}$, with a final extension at $72^{\circ} \mathrm{C}$ for $10 \mathrm{~min}$. Amplification of $h c n A B$ was performed using the forward primer PM2 (31-mer 5'-TGCGGCATGGGCGTGT GCCATTGCTGCCTGG-3') and the reverse primer PM726R (26-mer 5'-CCGCTCTTGATCTGCAATTGCAGGCC$3^{\prime}$ ) (Svercel et al., 2007), as described above. The PCR was initiated with denaturation $\left(2 \mathrm{~min}\right.$ at $\left.94{ }^{\circ} \mathrm{C}\right)$ and was followed by 35 cycles of $94^{\circ} \mathrm{C}$ for $30 \mathrm{~s}, 67^{\circ} \mathrm{C}$ for $30 \mathrm{~s}$ and $72^{\circ} \mathrm{C}$ for $60 \mathrm{~s}$ and a final extension at $72{ }^{\circ} \mathrm{C}$ for $10 \mathrm{~min}$.

Primers were synthesized by MWG Biotech (Basel, Switzerland), and amplifications were performed using a PTC-
100TM cycler (MJ Research Inc., Watertown, MA). The PCR products were separated in $1.5 \%$ agarose gels in $0.5 \times$ Trisborate-EDTA (TBE) buffer at $160 \mathrm{~V}$ for $1 \mathrm{~h}$.

\section{Statistics}

MPN data (expressed $\mathrm{g}^{-1}$ of fresh root) were $\log _{10}$-transformed (Loper et al., 1984) and the percentages of $p h l D^{+}$ and $h c n A B^{+}$pseudomonads were arcsine-transformed before statistical analyses. A first ANOVA was performed for data from the eight grapevine soils, using monoculture duration (i.e. long term or short term; factor 'age'), soil batch (i.e. A or B; factor 'batch'), geographic region (i.e. Basel, Neuchâtel, Valais or Zürich; factor 'location') and plant species (grapevine or tobacco; factor 'plant') as four factors, and the results are given in Table 2. For each soil batch and each plant species, further analyses of variance were then performed after inclusion of data from Morens soil MS8, i.e. for analysis of data sets encompassing the two sites for each of the four vineyard regions and Morens (nine treatments), and/or for analysis of data sets to compare each site (long-term vs. short-term vineyard) separately, whose results are displayed in Figs 1 and 2 and in Figs S2 and S3. The transformed data as well as the raw data were also subjected to a correlation analysis in relation to the actual duration of grapevine monoculture, using Pearson's correlation coefficient and Bonferroni's probability. All analyses were performed at $P<0.05$ (and sometimes also at $P<0.10$ ), using sYSTAT version 9 (SPSS Inc., Chicago, IL).

\section{Analysis of dominant phID alleles}

For each dilution series, phlD alleles were analysed in the last phlD-positive MPN well (often the same dilution for different samples). Each restriction analysis was performed on $5 \mu \mathrm{L}$ of DNA solution, using $1.5 \mathrm{U}$ of either HaeIII, MspI or TaqI (Boehringer, Mannheim) over $3 \mathrm{~h}$ at $37^{\circ} \mathrm{C}$ (HaeIII, MspI) or $60^{\circ} \mathrm{C}$ (TaqI). Restriction fragments were separated by electrophoresis in ethidium bromide-stained 2.5\% agarose gels, as described (Sambrook et al., 1989). A 100-bp ladder (GIBCO-BRL Life Technologies Inc., Gaithersburg, MD) was used as a molecular size marker. phlD restriction patterns were compared with those of reference strains, according to the system of McSpadden Gardener et al. (2001, 2005). For each locus, the findings presented were obtained after gathering data from RFLP analyses performed from the last phlD-positive MPN well from two different serial dilutions per plant.

For each of the 18 location $\times$ plant $\times$ age combinations (i.e. nine combinations per plant), the following comparison criteria were computed based on phlD allele data. First, the sum of the different phlD alleles $(\Sigma)$ and the dominance index of phlD allele $\mathrm{K}$ ( $\beta=$ occurrence of the $\mathrm{K}$ allele/ occurrence of all alleles) were determined. Second, the 
Table 2. Probability of variance distribution determined by ANOvA with the four factors age (monoculture duration), batch (soil batch), location (geographic region) and plant (plant species)

\begin{tabular}{|c|c|c|c|c|c|}
\hline Factors & $\begin{array}{l}\text { Number total } \\
\text { pseudomonads } \\
\text { (log CFU g }{ }^{-1} \text { roots) }\end{array}$ & $\begin{array}{l}\text { Number phlD } \\
\text { pseudomonads } \\
\text { (log CFU g }{ }^{-1} \text { roots) }\end{array}$ & $\begin{array}{l}\text { Proportion phlD } \\
\text { pseudomonads (\%) }\end{array}$ & $\begin{array}{l}\text { Number hcnAB } \\
\text { pseudomonads } \\
\text { (log CFU g }{ }^{-1} \text { roots) }\end{array}$ & $\begin{array}{l}\text { Proportion } h c n A B^{+} \\
\text {pseudomonads (\%) }\end{array}$ \\
\hline Age & 0.476 & $<0.001^{*}$ & $<0.001^{*}$ & $0.022^{*}$ & $<0.001^{*}$ \\
\hline Batch & $<0.001^{*}$ & 0.065 & $<0.001^{*}$ & $<0.001^{*}$ & 0.303 \\
\hline Location & $<0.001^{*}$ & $<0.001^{*}$ & $<0.001^{*}$ & $<0.001^{*}$ & $<0.001^{*}$ \\
\hline Plant & $<0.001^{*}$ & $<0.001^{*}$ & $<0.001^{*}$ & $<0.001^{*}$ & $0.001^{*}$ \\
\hline Batch $\times$ location & 0.280 & 0.566 & 0.405 & $0.004^{*}$ & $<0.001^{*}$ \\
\hline Batch $\times$ plant & $<0.001^{*}$ & $<0.001^{*}$ & 0.639 & $<0.001^{*}$ & 0.316 \\
\hline Batch $\times$ age & 0.833 & 0.942 & $0.013^{*}$ & 0.497 & 0.346 \\
\hline Location $\times$ plant & 0.102 & $0.014^{*}$ & $<0.001^{*}$ & 0.109 & $0.012^{*}$ \\
\hline Location $\times$ age & 0.634 & 0.148 & $0.007^{*}$ & 0.062 & $<0.001^{*}$ \\
\hline Plant $\times$ age & 0.286 & $0.026^{*}$ & $<0.001^{*}$ & $0.002^{*}$ & $<0.001^{*}$ \\
\hline Batch $\times$ location $\times$ plant & $0.032^{*}$ & 0.672 & $0.005^{*}$ & 0.119 & 0.161 \\
\hline Batch $\times$ location $\times$ age & 0.160 & 0.515 & $<0.001^{*}$ & $0.036^{*}$ & 0.205 \\
\hline Batch $\times$ plant $\times$ age & 0.057 & 0.707 & $0.013^{*}$ & $0.041^{*}$ & 0.806 \\
\hline Location $\times$ plant $\times$ age & 0.247 & $<0.001^{*}$ & $<0.001^{*}$ & $0.027^{*}$ & $<0.001^{*}$ \\
\hline Batch $\times$ location $\times$ plant $\times$ age & $0.017^{*}$ & $0.010^{*}$ & $0.019^{*}$ & $0.010^{*}$ & 0.807 \\
\hline
\end{tabular}

*Probability is significant at $P<0.05$ level.

diversity of the phlD alleles was evaluated with regard to the number of phlD alleles identified (i.e. richness) using Shannon's $H^{\prime}$ index, and the distribution of phlD alleles among rhizosphere samples (i.e. equitability) using Shannon's $E$ index (Shannon \& Weaver, 1949). Equitability was computed from $H^{\prime}$ and the total number of different phlD alleles $(N)$ as follows: $E=H^{\prime} / \ln N$. In addition, the ratio of the occurrence of allele $\mathrm{K}$ in grapevine by that in tobacco $(\alpha)$ was determined for each of the nine soils. For the grapevine soils (i.e. the eight 'age' $\times$ 'location' combinations), correlation analyses were performed (as described above; $n=8$ ) to investigate the relation between monoculture duration and (1) $\Sigma, \beta, H^{\prime}$ or $E$ determined for grapevine plantlets, (2) $\Sigma$, $\beta, H^{\prime}$ or $E$ determined for tobacco and (3) $\alpha$ (see Table 3 ).

\section{Results}

\section{Effect of long-term monoculture on the total number of fluorescent pseudomonads}

When grapevine or tobacco plantlets were grown in the soils collected, the total number of culturable fluorescent pseudomonads in the rhizosphere (i.e. $10^{8}-10^{9} \mathrm{~g}^{-1}$ root) depended significantly on the soil batch, the geographic region and the plant species, but not on whether monoculture was short or long (Table 2, Figs 1 and 2, Figs S2 and S3). Indeed, there was no significant correlation (not shown) between the actual duration of grapevine monoculture and the total number of fluorescent pseudomonads in the rhizosphere (Figs S2 and S3).

\section{Effect of long-term monoculture on the numbers of phID and hcnAB fluorescent pseudomonads}

Based on MPN data, phlD ${ }^{+}$and $h c n A B^{+}$pseudomonads represented, respectively, $5-57 \%$ and $17-47 \%$ of all culturable fluorescent pseudomonads in the rhizosphere for both grapevine and tobacco plantlets (Figs 1 and 2). Whether the soil used to grow plantlets originated from short- or longterm grapevine monoculture sites had a statistically significant impact on both the number and the percentage of rhizosphere $p h l D^{+}$pseudomonads, as well as on both the number and the percentage of rhizosphere $h \mathrm{cnAB}{ }^{+}$pseudomonads (Table 2). Indeed, soils with a long-term monoculture history were associated with higher values for the number $\left(6.0 \times 10^{7}\right.$ vs. $2.3 \times 10^{7} \mathrm{~g}^{-1}$ root $)$ and the percentage $(23 \%$ vs. $13 \%)$ of rhizosphere phlD ${ }^{+}$pseudomonads, and the number $\left(7.7 \times 10^{7}\right.$ vs. $3.2 \times 10^{7} \mathrm{~g}^{-1}$ root $)$ and the percentage ( $32 \%$ vs. $26 \%$ ) of rhizosphere $h c n A B^{+}$pseudomonads (Figs 1 and 2). ANOva indicated that the results also depended on the geographic region and the plant species (for all four variables) and to a lesser extent on the soil batch (only for the percentage of $p h l D^{+}$pseudomonads and the number of $h c n A B^{+}$pseudomonads) (Table 2).

When only results from the grapevine plantlet rhizosphere were considered, each older vineyard soil yielded an apparently higher percentage of rhizosphere phlD ${ }^{+}$pseudomonads compared with its younger counterpart (Fig. 1), and the difference was statistically significant in seven of eight cases (in the regions Basel, Neuchâtel and Valais with soil batch A, vs. in all four vineyard locations with batch B). 
(a)
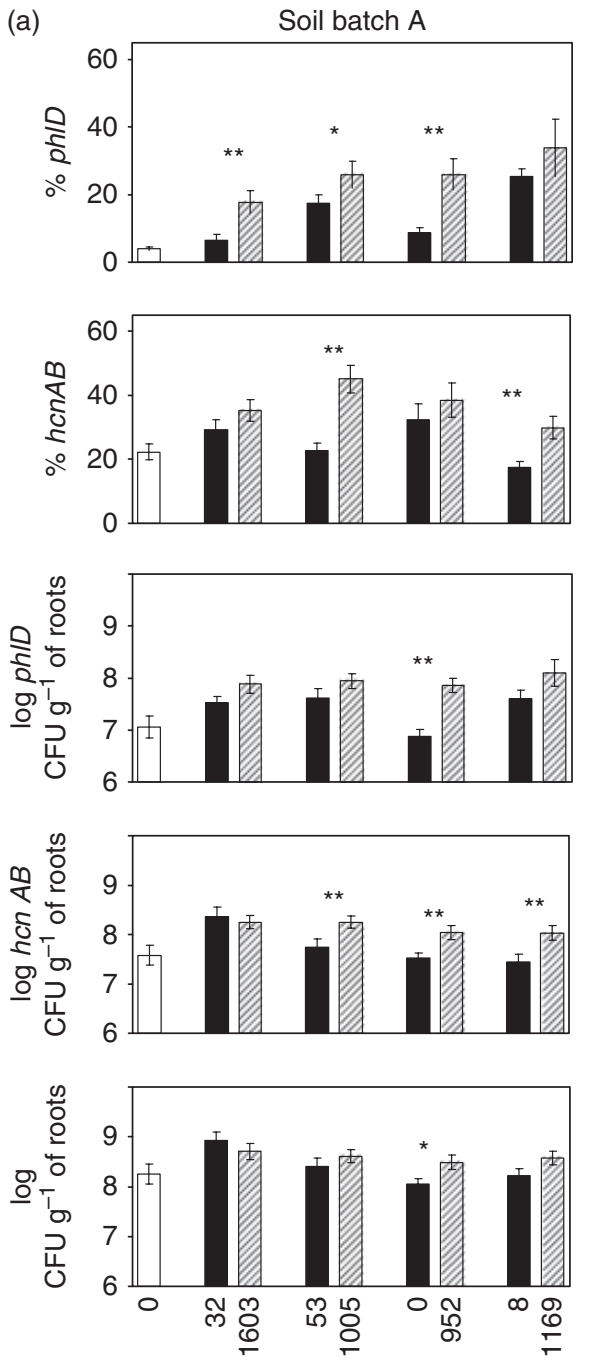

MS8 Basel Neuchâtel Valais Zürich (b)
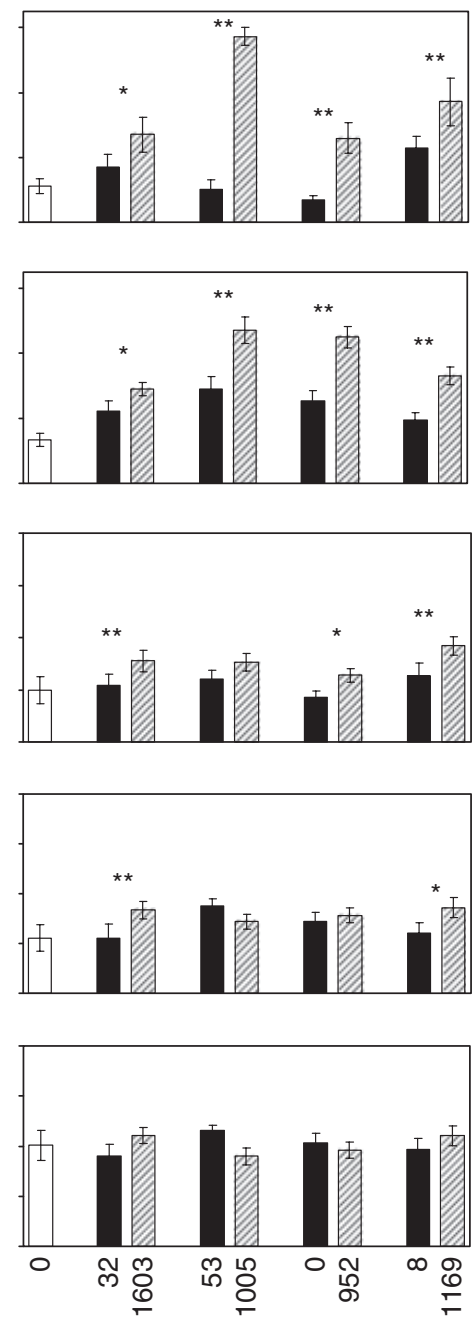

MS8 Basel Neuchâtel Valais Zürich
Fig. 1. Differences between young vineyards (black bars), old vineyards (grey bars) and crop rotation soil (white bars; MS8) in terms of the frequencies of $p h / D^{+}$and $h \subset n A B^{+}$pseudomonads, and the numbers of $p h / D^{+}, h \subset n A B^{+}$and total pseudomonads obtained from grapevine roots. The numbers above region names represent the duration of grapevine monoculture. The soil batches $A$ and $B$ represent duplicated experiments. ANOVA was performed on data sets encompassing the two sites for each of the four vineyard regions (separate comparison of long-term vs. short-term vineyard). For each soil batch, data are shown as means \pm SE $(n=8)$ and significant differences $(P<0.1 ; 0.05)$ are indicated by asterisks $(* ; * *)$. The effect of the duration of grapevine monocultures on pseudomonad populations is shown in Fig. S2.
Similarly, the number of $p h l D^{+}$pseudomonads was higher in old monocultures and differed statistically in four of eight cases (in the region Valais with soil batch $A$, and in the regions Basel, Valais and Zürich with batch B). Similarly, the percentage of rhizosphere $h c n A B^{+}$pseudomonads was seemingly higher for older vineyard soils (in most cases), and the differences were statistically significant in six of the eight individual old/young comparisons (Fig. 1). Concerning the number of $h c n A B^{+}$pseudomonads, the rhizosphere populations were significantly larger in five of eight cases in longterm monoculture soils compared with the short-term counterparts (Fig. 1). When data were assessed based only on the actual duration of grapevine monoculture, without considering the four regions, longer durations did not consistently translate into increased numbers and percentages of $p h l D^{+}$pseudomonads and of $h c n A B^{+}$pseudomonads in plantlet rhizospheres (Fig. S2). However, a significantly positive correlation was found with the number of rhizosphere $p h l D^{+}$pseudomonads in soil batches A $(r=0.76, n=9$ and $P=0.017)$ and $\mathrm{B}(r=0.82, n=9$ and $P=0.007)$ and the number of rhizosphere $h c n A B^{+}$pseudomonads in soil batch A only $(r=0.88, n=9$ and $P=0.002)$.

When tobacco was used as bait, the numbers of $p h l D^{+}$, $h c n A B^{+}$and total culturable pseudomonads in the rhizosphere were often lower (by $0.5-1.5 \log \mathrm{g}^{-1}$ root) in comparison with grapevine data (Figs 1 and 2). In many cases, the percentages of $p h l D^{+}$and $h c n A B^{+}$pseudomonads were less on tobacco than on grapevine. The main exception was Morens, a soil without a grapevine history, where the percentages of $p h l D^{+}$and of $h c n A B^{+}$pseudomonads in the rhizosphere were higher with tobacco than with grapevine.

When the effect of long-term grapevine monoculture was assessed based only on results from the tobacco rhizosphere, the trend was similar as to that of grapevine plants in the case of the number and percentage of $p h l D^{+}$pseudomonads when using soil from the three regions (Basel, Neuchâtel and 
Fig. 2. Differences between young vineyards (black bars), old vineyards (grey bars) and crop rotation soil (white bars; MS8) in terms of the frequencies of $p h / D^{+}$and $h c n A B^{+}$pseudomonads, and the numbers of $p h I D^{+}, h \subset n A B^{+}$and total pseudomonads obtained from tobacco roots. The numbers above region names represent the duration of grapevine monoculture. ANOva was performed on data sets encompassing the two sites for each of the four vineyard regions (separate comparison for long-term vs. shortterm vineyard). The soil batches $A$ and $B$ represent duplicated experiments. For each soil batch, data are shown as means \pm SE $(n=8)$ and significant differences $(P<0.1 ; 0.05)$ are indicated by asterisks $(* ; *)$. The effect of the duration of grapevine monocultures on pseudomonad populations is shown in Fig. S3. (a)
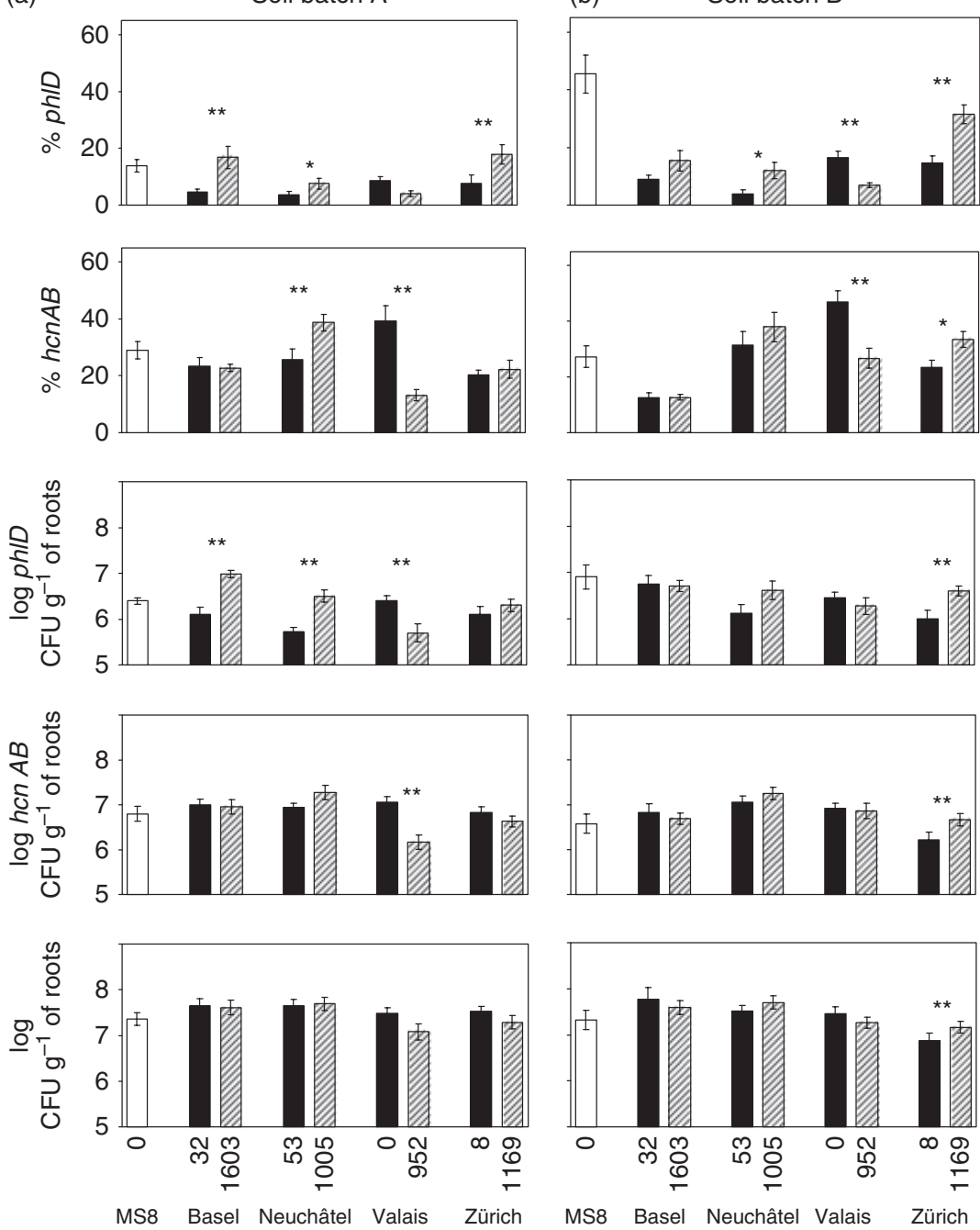
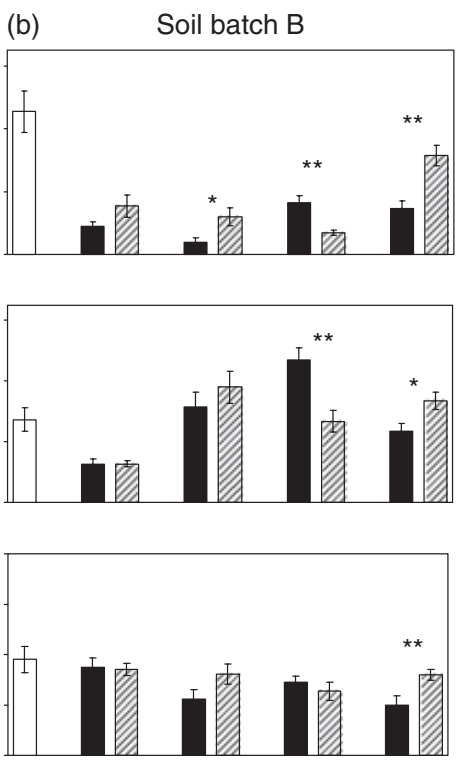

Zürich) where the rhizosphere levels were higher in longterm than in short-term vineyard soils (Fig. 2). The trend was statistically significant in eight of the 12 individual old/ young comparisons. There was a different situation in these three regions in terms of the number and percentage of $h c n A B^{+}$pseudomonads, where the values were significantly higher in just three of the 12 individual old/young comparisons. Unlike with soils from these three regions, growing tobacco in the old Valais vineyard soil yielded lower numbers of $p h l D^{+}$and of $h c n A B^{+}$pseudomonads (for soil batch A), as well as lower percentages of $p h l D^{+}$pseudomonads (for soil batch B) and $h c n A B^{+}$pseudomonads (for both soil batches).

\section{Diversity of the phID gene}

RFLP patterns of phlD amplicons from the last phlDpositive dilution wells (i.e. of dominant phlD alleles) were assessed by summing band sizes (to determine the number of alleles), and by comparison with 58 reference strains from a worldwide collection (McSpadden Gardener et al., 2000, 2005; Wang et al., 2001). For the 288 plants (tobacco and grapevine), only one allele was found, except that 11 of the 144 tobacco plants revealed two phlD alleles ( $4 \%$ from the total number of plants tested). When two alleles were identified in the same well, one typically yielding a less intense band, they were also identified (this time alone) for another plant grown in the same soil.

Five previously known phlD alleles i.e. A (documented in strains CHA0 and Pf-5), D (strains C*1A1 and Q8R1-96), F (strains JMP6 and JMP6R), K (strain F113) and M (strains PITR2 and D27B1) and two new alleles (designated $U$ and V) were detected. Screening of laboratory collections enabled identification of allele $U$ in strain Q37-87, which was previously characterized as rep-PCR genotype E (McSpadden Gardener et al., 2000), but that yielded a different profile 
Table 3. Occurrence of ph/D alleles, as indicated by the number of plants from which the alleles were found*

\begin{tabular}{|c|c|c|c|c|c|c|c|c|c|c|c|c|c|}
\hline \multirow[b]{2}{*}{ Treatment } & \multirow{2}{*}{$\begin{array}{l}\text { Years of } \\
\text { grapevine } \\
\text { monoculture }\end{array}$} & \multicolumn{7}{|c|}{ phID alleles } & \multirow[b]{2}{*}{$\Sigma^{\dagger}$} & \multirow[b]{2}{*}{$\alpha^{\ddagger}$} & \multirow[b]{2}{*}{$\beta^{\S}$} & \multirow[b]{2}{*}{$H^{\prime}$} & \multirow[b]{2}{*}{$E^{\|}$} \\
\hline & & A & $\mathrm{D}$ & $\mathrm{F}$ & $\mathrm{K}$ & M & U & v & & & & & \\
\hline \multicolumn{14}{|l|}{ Grapevine } \\
\hline Morens MS8 & 0 & & 1 & 8 & 5 & & & & 3 & 0.6 & 0.36 & 0.87 & 0.80 \\
\hline \multirow[t]{2}{*}{ Basel } & 32 & & 2 & 6 & 5 & & & & 3 & 1.0 & 0.39 & 1.00 & 0.91 \\
\hline & 1603 & & & 4 & 9 & & & & 2 & 3.0 & 0.69 & 0.62 & 0.89 \\
\hline \multirow[t]{2}{*}{ Neuchâtel } & 53 & 2 & 2 & & 12 & & & & 3 & 1.1 & 0.75 & 0.74 & 0.67 \\
\hline & 1005 & & & & 15 & & & & 1 & 5.0 & 1.00 & 0.00 & 0.00 \\
\hline \multirow[t]{2}{*}{ Valais } & 0 & & & & 16 & & & & 1 & 1.0 & 1.00 & 0.00 & 0.00 \\
\hline & 952 & & & & 16 & & & & 1 & 1.5 & 1.00 & 0.00 & 0.00 \\
\hline \multirow[t]{2}{*}{ Zürich } & 8 & & & & 14 & & & & 1 & 2.3 & 1.00 & 0.00 & 0.00 \\
\hline & 1169 & 1 & 2 & 1 & 9 & & & & 4 & 4.5 & 0.69 & 0.94 & 0.68 \\
\hline \multicolumn{14}{|l|}{ Tobacco } \\
\hline Morens MS8 & 0 & 1 & & 5 & 8 & & & & 3 & & 0.57 & 0.87 & 0.80 \\
\hline \multirow[t]{2}{*}{ Basel } & 32 & 4 & & 5 & 5 & 1 & & & 4 & & 0.33 & 1.27 & 0.92 \\
\hline & 1603 & 1 & 3 & 3 & 3 & 1 & 2 & & 6 & & 0.23 & 1.70 & 0.95 \\
\hline \multirow[t]{2}{*}{ Neuchâtel } & 53 & 2 & 1 & 1 & 11 & & & & 4 & & 0.73 & 0.86 & 0.62 \\
\hline & 1005 & 1 & & 1 & 3 & 3 & 3 & 1 & 6 & & 0.25 & 1.65 & 0.91 \\
\hline \multirow[t]{2}{*}{ Valais } & 0 & & & & 16 & & & & 1 & & 1.00 & 0.00 & 0.00 \\
\hline & 952 & 1 & & 3 & 11 & & & & 3 & & 0.73 & 0.74 & 0.67 \\
\hline \multirow[t]{2}{*}{ Zürich } & 8 & 1 & 1 & 2 & 6 & 1 & 2 & 1 & 7 & & 0.43 & 1.66 & 0.85 \\
\hline & 1169 & 2 & 2 & 1 & 2 & 1 & 1 & 3 & 7 & & 0.17 & 1.83 & 0.94 \\
\hline Number of plants & & 15 & 14 & 40 & 166 & 7 & 8 & 5 & & & & & \\
\hline
\end{tabular}

*Combined results obtained when studying soil batches A and B. For each dilution series, phID alleles were analyzed in the last phID-positive MPN well. †Sum of different phID alleles.

${ }^{\ddagger}$ Ratio of the occurrence of allele $\mathrm{K}$ in grapevine/occurrence of allele $\mathrm{K}$ in tobacco.

\$Dominance index of phID allele K ( = occurrence of allele K/occurrence of all alleles).

'Shannon's richness index.

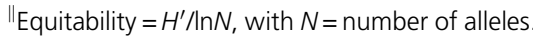

here with HaeIII, and allele V in strain K93.2. Four alleles were obtained on both grapevine and tobacco (A, D, F and $\mathrm{K})$ and the three others ( $\mathrm{M}, \mathrm{U}$ and $\mathrm{V}$ ) exclusively on tobacco (Table 3). The most frequent allele was $\mathrm{K}$, which was found in all treatments, followed by alleles $\mathrm{F}$ and $\mathrm{A}$, detected in $>50 \%$ of the MPN wells studied.

When grapevine was used as bait, the number of phlD alleles in long-term vineyard soils was higher (Zürich, four vs. one allele), identical (Valais, one allele) or lower (Basel, two vs. three alleles; Neuchâtel, one vs. three) than in the short-term counterparts and this paralleled the prevalence of allele $\mathrm{K}$ (i.e. higher when the allele number was lower) (Table 3). When tobacco was used, the number of phlD alleles in long-term vineyard soils was higher (Valais, three vs. one allele; Basel, six vs. four; and Neuchâtel, six vs. four, as allele $\mathrm{K}$ was less frequent) or identical (Zürich, seven alleles) in comparison with the short-term counterparts. Overall, allele K was found with $85 \%$ of grapevine plantlets and $35 \%$ of tobacco plantlets in long-term monoculture soils, vs., respectively, $78 \%$ and $62 \%$ in the short-term counterparts. The presence or absence of allele $\mathrm{K}$ in these rhizosphere samples was confirmed on testing other (randomly selected) MPN wells corresponding to lower phlD- positive dilutions (not shown). In addition, the ratio between grapevine and tobacco for allele $\mathrm{K}$ was $50 \%$ higher or more for plants grown in long-term monoculture soils vs. short-term counterparts in the four regions. Shannon's $H^{\prime}$ index was identical or lower when comparing grapevine vs. tobacco baiting plants (Table 3 ). However, $H^{\prime}$ was essentially similar for long-term monoculture soils and short-term counterparts, regardless of whether grapevine or tobacco was considered. In addition, there was no significant correlation between monoculture duration and (1) $\Sigma, \beta, H^{\prime}$ or $E$ determined for grapevine plantlets, (2) $\Sigma, \beta, H^{\prime}$ or $E$ determined for tobacco and (3) $\alpha$.

\section{Discussion}

Grapevine is a perennial plant, and each year the roots, leaves and small branches are left to decompose and contribute to the organic matter status of the top soil (i.e. the soil layer that was sampled in this study). In addition, root exudates and root architecture modify soil quality and structure. Despite differences in the soil composition, microclimatic conditions, grapevine cultivars and plot management from one region to the other, it is expected that 
these factors had cumulated and developed to a much higher extent in long-term grapevine monoculture in comparison with short-term grapevine monoculture. In this context, four pairs of sites were selected for the current work. It is important to note that two major crop management features have been implemented over the last century, i.e. the exclusive use of a few foreign rootstocks for insect resistance (Granett et al., 2001) and yearly treatments with copper sulphate against fungal pathogens. This concerned all current sites, except the brushland in Valais and soil MS8 in Morens, as illustrated by much lower soil copper contents (Table 1).

This work was based on the hypothesis that sustainable, long-term grapevine monoculture should lead to an enrichment in antagonistic pseudomonads, and indeed statistical analyses indicated that the rhizosphere of plantlets grown in long-term grapevine monoculture soils displayed a higher number and percentage of $p h l D^{+}$pseudomonads, as well as a higher number and percentage of $h c n A B^{+}$pseudomonads, but it had no significant impact on the total number of rhizosphere pseudomonads. Similar findings were obtained when grapevine plantlet data were analysed separately, one soil batch at a time, but the statistical power was less and the differences were statistically significant for most, but not all pair of soils. Interestingly, when tobacco was used as bait, the percentages of rhizosphere $p h l D^{+}$pseudomonads remained higher in long-term monoculture soils in comparison with neighbouring short-term vineyard soils. $p h l D^{+}$pseudomonads from laboratory collections are also $\mathrm{HCN}^{+}$, except one strain (Wang et al., 2001), in which the hcnABC locus is inactivated (Rezzonico et al., 2007). Here, the $h c n A B^{+}$ population was higher than the $p h l D^{+}$population, pointing to the presence of $p h l D^{+} h c n A B^{+}$pseudomonads as well as phlD ${ }^{-} h c n A B^{+}$strains. In accordance with the current results, the $p h l D^{+}$population was higher in soil after a century of wheat and/or flax monoculture than under crop rotation (Landa et al., 2006). In addition, the percentage of rhizosphere $p h l D^{+}$pseudomonads was higher in a soil suppressive to black root rot than in a conducive soil (Ramette et al., 2003b).

Morens soil MS8 was included in the study as a reference, because the tobacco rhizosphere is known to select $\mathrm{Phl}^{+}$ $\mathrm{HCN}^{+}$pseudomonads in this soil (Ramette et al., 2003b). The current results indicate that the enrichment of $p h l D^{+}$ and/or $h c n A B^{+}$pseudomonads in the grapevine rhizosphere was higher in grapevine soils (especially under long-term monoculture) compared with Morens soil, but this was not the case in the tobacco rhizosphere. On the one hand, in Morens soil, which was probably never planted with grapevine, tobacco plantlets baited a similar or a higher percentage of $p h l D^{+}$pseudomonads (but not $\mathrm{HCN}^{+}$ pseudomonads) than did grapevine plantlets. On the other hand, when we baited long-term monoculture grapevine soils with tobacco (a plant not present in the vineyards, but that grew well in these soils), the percentage of $p h l D^{+}$ pseudomonads (but not $\mathrm{HCN}^{+}$pseudomonads) was lower than when grapevine plantlets were used. These results suggest that grapevine monoculture has favoured grapevine-adapted $p h l D^{+}$pseudomonads, and this hypothesis was assessed by studying phlD alleles.

Four dominant phlD alleles were recovered from the grapevine rhizosphere vs. as many as seven from tobacco. This latter number is high, as Landa et al. (2002b) and McSpadden Gardener et al. (2000) found a maximum of four phlD alleles per field sample using the same 629-bp phlD amplicon as in the present study (vs. up to four alleles with a 745-bp phlD amplicon; Ramette et al., 2001). Here, the lower number of dominant phlD alleles on grapevine was explained by a higher prevalence of allele $\mathrm{K}$, and up to $85 \%$ of grapevine plantlets displayed this allele in long-term vineyard monoculture soils. Therefore, $\mathrm{phlD}^{+}$pseudomonads less competitive for rhizosphere colonization of grapevine plantlets than those displaying phlD allele $\mathrm{K}$ managed to survive as soil saprophytes and could be baited by tobacco. Moreover, the long-term monoculture soils maintained a higher number of phlD alleles (revealed after baiting by tobacco plants) than the short-term monoculture soils in the three sites where both types of soils are located side by side (i.e. Basel, Neuchâtel and Valais). Allele $\mathrm{K}$ is found in the well-studied biocontrol strain Pseudomonas fluorescens F113, and interestingly F113-like pseudomonads were readily evidenced in the strawberry rhizosphere by PCR-denaturing gradient gel electrophoresis targeting the 16S rRNA gene (Costa et al., 2006) or gacA (Costa et al., 2007). Picard \& Bosco (2006) found that maize hybrids and their parents selected different phlD alleles, and distinct genotypes of phlD ${ }^{+}$pseudomonads were enriched during monoculture, whereas only one phlD allele had been detected under crop rotation (Landa et al., 2006; Weller et al., 2007). The larger number of distinct alleles in the current case compared with long-term monocultures of annual plants such as wheat and flax (Landa et al., 2006) is perhaps due to a lower level of anthropogenic soil disturbance with perennial plant grapevine.

Soil properties varied more between regions than between adjacent vineyards. Abiotic factors (Ownley et al., 2003) and soil type (Latour et al., 1996; Dalmastri et al., 1999; Marschner et al., 2001) are known to influence the composition of microbial populations and the production of biocontrol metabolites important for microbial survival (Duffy \& Défago, 1999; Haas \& Keel, 2003). Here, it remains to be examined as to how soil properties could also have influenced the selection of specific Pseudomonas genotypes, similar to the observation that zinc and certain other microelements can select for mutant subpopulations in pseudomonads (Duffy \& Défago, 2000). 
In conclusion, we have identified a positive effect of longterm grapevine monoculture on the number and percentage of rhizosphere-colonizing pseudomonads carrying the biocontrol genes $p h l D^{+}$and/or $h c n A B^{+}$. Pseudomonas strains displaying allele $\mathrm{K}$ were highly prevalent in the grapevine rhizosphere (i.e. $>60 \%$ ), regardless of the soil, but in longterm grapevine monoculture soils, they were in a minority in the tobacco rhizosphere (but not in the grapevine rhizosphere). A lower prevalence of allele $\mathrm{K}$ coincided with higher numbers of the other dominant phlD alleles. This means that tobacco was useful to recover alternative $p h l D^{+}$genotypes, which are less adapted to grapevine. We conclude that long-term grapevine monoculture soils represent an untapped resource for isolating new Pseudomonas strains with potential biocontrol activity, when tobacco is used to bait the rhizosphere pseudomonads.

\section{Acknowledgements}

This project was funded by the National Centre of Competence in Research (NCCR) Plant Survival, a research programme of the Swiss National Science Foundation. Support for B. Duffy was provided by the Swiss Federal Office for Agriculture (BLW) Project 04.24.3.3. We are grateful to Lê Công-Lihn (Agroscope RAC Changins, Nyon, Switzerland) for providing in vitro propagated grapevine plants, Brian B. McSpadden Gardener (Department of Plant Pathology, Ohio State University, Wooster, $\mathrm{OH}$ ) and Linda S. Thomashow (USDA-ARS, Washington State University, WA) for providing us with reference pseudomonad strains.

\section{References}

Alexander M (1982) Most probable number method for microbial populations. Methods of Soil Analysis, Part 2, Chemical and Microbiological Properties - Agronomy Monograph no. 9 (Segoe S, ed), pp. 815-820. ASA-SSSA, Madison, WI.

Bangera MG \& Thomashow LS (1999) Identification and characterization of a gene cluster for synthesis of the polyketide antibiotic 2,4-diacetylphloroglucinol from Pseudomonas fluorescens Q2-87. J Bacteriol 181: 3155-3163.

Burr TS, Bazzi C, Sule S \& Otten L (1998) Crown gall of grape. Biology of Agrobacterium vitis and the development of disease control strategies. Plant Dis 82: 1288-1297.

Christen D (2001) Diversity of pseudomonad strains producing hydrogen cyanide and 2,4-diacetylphloroglucinol in grapevine monoculture. Master thesis, ETH Zurich, Switzerland.

Costa R, Salles JF, Berg G \& Smalla K (2006) Cultivationindependent analysis of Pseudomonas species in soil and in the rhizosphere of field-grown Verticillium dahliae host plants. Environ Microbiol 8: 2136-2149.

Costa R, Gomes NCM, Krögerrecklenfort E, Opelt K, Berg G \& Smalla K (2007) Pseudomonas community structure and antagonistic potential in the rhizosphere: insights gained by combining phylogenetic and functional gene-based analyses. Environ Microbiol 9: 2260-2273.

Dalmastri C, Chiarini L, Cantale C, Bevivino A \& Tabacchini S (1999) Soil type and maize cultivar affect the genetic diversity of maize root-associated Burkholderia cepacia populations. Microb Ecol 38: 273-284.

Duffy B \& Défago G (1999) Environmental factors modulating antibiotic and siderophore biosynthesis by Pseudomonas fluorescens biocontrol strains. Appl Environ Microb 65: 2429-2438.

Duffy B \& Défago G (2000) Controlling instability in gacS-gacA regulatory genes during inoculant production of Pseudomonas fluorescens biocontrol strains. Appl Environ Microb 66: 3142-3150.

Galzy R (1990) Remarques sur la nutrition carbonée de la vigne cultivée in vitro. Bull OIV 707: 6-20.

Garbeva PJ, van Veen A \& van Elsas JD (2004) Microbial diversity in soil: selection of microbial populations by plant and soil type and implications for disease suppressiveness. Annu Rev Phytopathol 42: 243-270.

Gardener BBM (2007) Diversity and ecology of biocontrol Pseudomonas spp. in agricultural systems. Phytopathology 97: 221-226.

Garthright WE \& Blodgett RJ (2003) FDA's preferred MPN methods for standard, large or unusual tests, with a spreadsheet. Food Microbiol 20: 439-445.

Granett JM, Walker A, Kocsis L \& Omer AD (2001) Biology and management of grape phylloxera. Annu Rev Entomol 46: 387-412.

Haas D \& Défago G (2005) Biological control of soil-borne pathogens by fluorescent pseudomonads. Nat Rev Microbiol 3: 307-319.

Haas D \& Keel C (2003) Regulation of antibiotic production in root-colonizing Pseudomonas spp. and relevance for biological control of plant disease. Annu Rev Phytopathol 41: 117-153.

Keel C, Schnider U, Maurhofer M, Voisard C, Laville J, Burger U, Wirthner P, Haas D \& Défago G (1992) Suppression of root diseases by Pseudomonas fluorescens CHA0: importance of the bacterial secondary metabolite 2,4-diacetylphloroglucinol. Mol Plant Microbe In 5: 4-14.

Keel C, Weller DM, Natsch A, Défago G, Cook RJ \& Thomashow LS (1996) Conservation of the 2,4-diacetylphloroglucinol biosynthesis locus among fluorescent Pseudomonas strains from diverse geographic locations. Appl Environ Microb 62: $552-563$.

King EO, Ward MK \& Raney DE (1954) Two simple media for the demonstration of pyocyanin and fluorescein. J Lab Clin Med 44: 301-307.

Landa BB, de Werd HAE, McSpadden Gardener BB \& Weller DM (2002a) Comparison of three methods for monitoring populations of different genotypes of 2,4diacetylphloroglucinol-producing Pseudomonas fluorescens in the rhizosphere. Phytopathology 92: 129-137. 
Landa BB, Mavrodi OV, Raaijmakers JM, McSpadden Gardener BB, Thomashow LS \& Weller DM (2002b) Differential ability of genotypes of 2,4-diacetylphloroglucinol-producing Pseudomonas fluorescens strains to colonize the roots of pea plants. Appl Environ Microb 68: 3226-3237.

Landa BB, Mavrodi OV, Schroeder KL, Allende-Molar R \& Weller DM (2006) Enrichment and genotypic diversity of phlDcontaining fluorescent Pseudomonas spp. in two soils after a century of wheat and flax monoculture. FEMS Microbiol Ecol 55: 351-368.

Latour X, Corberand T, Laguerre G, Allard F \& Lemanceau P (1996) The composition of fluorescent pseudomonads populations associated with roots is influenced by plant and soil type. Appl Environ Microb 62: 2449-2456.

Loper JE, Suslow TV \& Schroth MN (1984) Lognormal distribution of bacterial populations in the rhizosphere. Phytopathology 74: 1454-1460.

Marschner P, Yang C-H, Lieberei R \& Crowley DE (2001) Soil and plant specific effects on bacterial community composition in the rhizosphere. Soil Biol Biochem 33: 1437-1445.

Mavrodi OV, McSpadden Gardener BB, Mavrodi DV, Bonsall RF, Weller DM \& Thomashow LS (2001) Genetic diversity of phlD from 2,4-diacetylphloroglucinol-producing fluorescent Pseudomonas spp. Phytopathology 91: 35-43.

Mazzola M (2004) Assessment and management of soil microbial community structure for disease suppression. Annu Rev Phytopathol 42: 35-59.

Mazzola M, Funnell DL \& Raaijmakers JM (2004) Wheat cultivar-specific selection of 2,4-diacetylphloroglucinolproducing fluorescent Pseudomonas species from resident soil populations. Microb Ecol 48: 338-348.

McSpadden Gardener BB \& Weller DM (2001) Changes in populations of rhizosphere bacteria associated with take-all disease of wheat. Appl Environ Microb 67: 4414-4425.

McSpadden Gardener BB, Schroeder KL, Kalloger SE, Raaijmakers JM, Thomashow LS \& Weller DM (2000) Genotypic and phenotypic diversity of phlD-containing Pseudomonas strains isolated from the rhizosphere of wheat. Appl Environ Microb 66: 1939-1946.

McSpadden Gardener BB, Mavrodi DV, Thomashow LS \& Weller DM (2001) A rapid polymerase chain reaction-based assay characterizing rhizosphere populations of 2,4diacetylphloroglucinol-producing bacteria. Phytopathology 91 : 44-54.

McSpadden Gardener BB, Gutierrez LJ, Joshi R, Edema R \& Lutton E (2005) Distribution and biocontrol potential of phlD ${ }^{+}$pseudomonads in corn and soybean fields. Phytopathology 95: 715-724.

Moënne-Loccoz Y \& Défago G (2004) Life as a biocontrol pseudomonad. Pseudomonas: Genomics, Life Style and Molecular Architecture (Ramos JL, ed), pp. 457-476. Kluwer Academic/Plenum Publishers, New York, NY.

Okubara PA, Kornoely JP \& Landa BB (2004) Rhizosphere colonization of hexaploid wheat by Pseudomonas fluorescens strains Q8r1-96 and Q2-87 is cultivar-variable and associated with changes in gross root morphology. Biol Control 30: 392-403.

Ownley BH, Duffy BK \& Weller DM (2003) Identification and manipulation of soil properties to improve the biological control performance of phenazine-producing Pseudomonas fluorescens. Appl Environ Microb 69: 3333-3343.

Paulsen IT, Press CM, Ravel J et al. (2005) Complete genome sequence of the plant commensal Pseudomonas fluorescens Pf-5. Nat Biotechnol 23: 873-878.

Picard C \& Bosco M (2006) Heterozygosis drives maize hybrids to select elite 2,4-diacetylphloroglucinol-producing Pseudomonas strains among resident soil populations. FEMS Microbiol Ecol 58: 193-204.

Picard C, Frascaroli E \& Bosco M (2004) Frequency and biodiversity of 2,4-diacetylphloroglucinol-producing rhizobacteria are differentially affected by the genotype of two maize inbred lines and their hybrid. FEMS Microbiol Ecol 49: 207-215.

Raaijmakers JM, Weller DM \& Thomashow LS (1997) Frequency of antibiotic-producing Pseudomonas spp. in natural environment. Appl Environ Microb 63: 881-887.

Ramette A, Moënne-Loccoz Y \& Défago G (2001) Polymorphism of the polyketide synthase gene phlD in biocontrol fluorescent pseudomonads producing 2,4-diacetylphloroglucinol and comparison of PhlD with plant polyketide synthases. $\mathrm{Mol}$ Plant Microbe In 14: 639-652.

Ramette A, Frapolli M, Défago G \& Moënne-Loccoz Y (2003a) Phylogeny of $\mathrm{HCN}$ synthase-encoding $h \mathrm{cn} B C$ genes in biocontrol fluorescent pseudomonads and its relationship with host plant species and HCN synthesis ability. Mol Plant Microbe In 44: 35-43.

Ramette A, Moënne-Loccoz Y \& Défago G (2003b) Prevalence of fluorescent pseudomonads producing antifungal phloroglucinols and/or hydrogen cyanide in soils naturally suppressive or conducive to tobacco black root rot. FEMS Microbiol Ecol 44: 35-43.

Ramette A, LiPuma JJ \& Tiedje JM (2005) Species abundance and diversity of Burkholderia cepacia complex in the environment. Appl Environ Microb 71: 1193-1201.

Ramette A, Moënne-Loccoz Y \& Défago G (2006) Genetic diversity and biocontrol potential of fluorescent pseudomonads producing phloroglucinols and hydrogen cyanide from Swiss soils naturally suppressive or conducive to Thielaviopsis basicola-mediated black root rot of tobacco. FEMS Microbiol Ecol 55: 369-381.

Rezzonico F, Zala M, Keel C, Duffy B, Moënne-Loccoz Y \& Défago G (2007) Is the ability of biocontrol fluorescent pseudomonads to produce the antifungal metabolite 2,4diacetylphloroglucinol really synonymous with higher plant protection? New Phytol 173: 861-872.

Rotenberg D, Joshi R, Benitez MS, Chapin LG, Camp A, Zumpetta C, Osborne A, Dick WA \& Gardener BBM (2007) Farm management effects on rhizosphere colonization by native populations of 2,4-diacetylphloroglucinol-producing 
Pseudomonas spp. and their contributions to crop health. Phytopathology 97: 756-766.

Sambrook J, Fritsch EF \& Maniatis T (1989) Molecular Cloning: A Laboratory Manual, 2nd edn. Cold Spring Harbor Laboratory Press, Cold Spring Harbor, NY.

Schlegel W (1973) Der Weinbau in der Schweiz. Wiesbaden, Steiner.

Shannon CE \& Weaver W (1949) The Mathematical Theory of Communication. University of Illinois Press, Urbana, IL.

Stutz EW, Défago G \& Kern H (1986) Naturally occurring fluorescent pseudomonads involved in suppression of black root rot of tobacco. Phytopathology 76: 181-185.

Svercel M, Duffy B \& Défago G (2007) PCR amplification of hydrogen cyanide biosynthetic locus hcnAB in Pseudomonas spp. J Microbiol Meth 70: 209-213.

Wang C, Ramette A, Punjasamarnwong P, Zala M, Natsch A, Moënne-Loccoz Y \& Défago G (2001) Cosmopolitan distribution of phlD-containing dicotyledonous cropassociated biocontrol pseudomonads of worldwide origin. FEMS Microbiol Ecol 37: 105-116.

Weller DM, Raaijmakers JM, McSpadden Gardener BB \& Thomashow LS (2002) Microbial populations responsible for specific soil suppressiveness to plant pathogen. Annu Rev Phytopathol 40: 309-348.

Weller DM, Landa BB, Mavrodi OM, Schroeder KL, De la Fuente L, Blouin Bankhead S, Allende Molar R, Bonsall RF, Mavrodi DV \& Thomashow LS (2007) Role of 2,4diacetylphloroglucinol-producing fluorescent Pseudomonas spp. in the defence of plant roots. Plant Biol 9: 4-20.

Winkler AJ (1962) General Viticulture. University California Press, Berkeley, CA.

Ziegler H (1983) Die Nährstoffe und ihr Umsatz in der Pflanze. 2. Verfügbarkeit der Nährelemente. Lehrbuch der Botanik (Noll E,
Schenk FH \& Schimper AFW, eds), pp. 334-336. Gustav

Fischer Verlag, Stuttgart, Germany.

\section{Supporting Information}

Additional Supporting Information may be found in the online version of this article:

Fig. S1. Most probable number-PCR (MPN-PCR) approach to determine the population structure of rhizosphere colonizing pseudomonads with biocontrol relevant genes.

Fig. S2. Effect of duration of grapevine monocultures on the numbers and frequencies of $p h l D^{+}$or $h c n A B^{+}$pseudomonads and on the total pseudomonad population obtained from roots of grapevine grown in vineyard soils and in nonvineyard soils (brushland adjacent to a 952-years-old vineyard in Valais, and tobacco disease suppressive soil from Morens).

Fig. S3. Effect of duration of grapevine monocultures on the numbers and frequencies of $p h l D^{+}$or $h c n A B^{+}$pseudomonads and on the total pseudomonad population obtained from roots of tobacco grown in vineyard soils and in nonvineyard soils (brushland adjacent to a 952-years-old vineyard in Valais, and tobacco disease suppressive soil from Morens).

Please note: Wiley-Blackwell is not responsible for the content or functionality of any supporting materials supplied by the authors. Any queries (other than missing material) should be directed to the corresponding author for the article. 